\title{
Effect of Diet Regimen on Serum Vaspin Level in Obese Diabetic Female Patients
}

\author{
Sherif Wagih Mansour ${ }^{1}$, Mohammed Saed Tawfiq ${ }^{1}$,' Abeer Albiomy Khalefa ${ }^{1}$. Shaimaa \\ Elsayed Hadhoud ${ }^{1}$ Eman Abd Allah El-Shorbgy ${ }^{2}$
}

1. physiology department, Faculty of medicine, Zagazig University.

2. Internal medicine department, Faculty of medicine, Zagazig University

\section{Corresponding Author: Shaimaa Elsayed Hadhoud Assistant lecturer of physiology, Faculty of Medicine, Zagazig University, Egypt. \\ Shaimaa Hadhood@yahoo.com}

$\begin{array}{ll}\text { Submit Date } & 2019-03-17 \\ \text { Revise Date } & 2019-04-02 \\ \text { Accept Date } & 2019-04-02\end{array}$

\begin{abstract}
BACKGROUND: High serum vaspin concentrations and increased vaspin mRNA expression in human adipose tissue were associated with obesity, insulin resistance, and type II diabetes. However, the mechanisms how vaspin secretion may be linked to deterioration of glucose metabolism and insulin sensitivity are not understood. OBJECTIVES: The aim of this work is to explore the effect of dietary regimen for 6 months on serum vaspin levels in obese diabetic and non diabetic female patients. PATIENTS AND METHODS: The study was carried out in Zagazig University Hospital and Obesity management and research unit. The sample size was 40 obese female patients. All participants were screened to determine the eligibility for participation in the study according to specific inclusion and exclusion criteria.Control groups didn't follow any diet plan while mediterrnean diet group followed mediterrnean diet for 6 months. The following parameters were assessed at the beginning and after 6months:body mass index(BMI), waist circumference(WC),Homeostatic model assessment (HOMA), Atherogenic index (AI), creatinine clearance and circulating levels of vaspin, vitamin $\mathrm{D}$, Low density lipoprotein (LDL), High density lipoprotein (HDL), Triglyecrides (TG), Total cholesterol (TC), glucose,insulin,HbA1c, Superoxide dismutase (SOD) and Malondialdehyde (MDA). RESULTS: Mediterrnean diet life style for 6 months resulted in a significant decrease in BMI, WC, HOMA, AI, vaspin, LDL, TG, TC,glucose, insulin,HbAlc and MDA with a significant increase in HDL,SOD and vitamin D. CONCLUSION: Elevated serum vaspin and low VitD levels are encountered in obesity.So, vaspin may be used as a novel biomarker for obesity, insulin resistance and TypeII DM management.
\end{abstract}

KEY WORDS: Vaspin, Adipokines, Obesity, Type II DM

\section{INTRODUCTION}

V aspin was initially isolated from visceral white adipose tissues (VAT) of abdominal obesity with type II diabetes mellitus Otsuka Long-Evans Tokushima fatty (OLETF) rats ${ }^{[1] .}$ The unique mechanism of vaspin is not known ${ }^{[2]}$ Many studies found a positive correlation between Vaspin gene expression and metabolic syndrome (Mets) components ${ }^{[3,4]}$, while others found no association between Vaspin and insulin resistance. ${ }^{[5-8] .}$ Data on serum vaspin levels in Type II DM are conflicting ${ }^{[8]}$. Noteworthy, vaspin levels were reduced in subjects with
BMI $<25 \mathrm{~kg} / \mathrm{m} 2$ and in those with long-term physical activity $[\mathbf{9 , 1 0 ]}$. Blüher revealed permanent decrease in vaspin levels after 2year Mediterranean low-carbohydrate, or lowfat diet ${ }^{[11] .}$. Meanwhile, Koiou et al. and Martos-Moreno et al. did not find variation in vaspin level in different weight loss interventions [12,13]. Kim et al.described no change in vaspin levels after a 10-month program of life style modification in MetS patients ${ }^{[14]}$. The intimate relation between vaspin, obesity and diabetes is not clearly understood so our study was designed to determine the role of vaspin in obesity and 
insulin sensitivity and its relation with weight loss and diet regulating glucose metabolism.

\section{SUBJECTS AND METHODS}

This study was carried out on 40 adult female patients (We started our study with 60 patients but only 40 of them completed the study) matched for age and BMI: 18 obese type II diabetic patients and 22 obese non diabetic control subjects attending the outpatient clinic of Obesity Management and Research Unit and Internal medicine department, faculty of medicine Zagazig university hospitals. Written informed consent was obtained from all participants and the study was approved by the research ethical committee of Faculty of Medicine, Zagazig University(approval no.3048, date 6-9-2016). The work has been carried out in accordance with The Code of Ethics of the World Medical Association (Declaration of Helsinki) for studies involving humans.

Inclusion criteria: Non pregnant female patients with age from 20 to 45 years, Type II DM treated by biguanides and sulphonylurea. Exclusion criteria: Male, younger than 20 years old or older than 45years old, other endocrinal disorders as myxodema, or Pregnant females.

\section{Patients are classified into:}

1. Obese non diabetic female patients (obese group): $n=22$. It was subdivided into 2 subgroups: Control (group 1): $\mathrm{n}=10$, Mediternean diet (MD) (group 2) $: \mathrm{n}=12$

2. Obese diabetic female patients (obese diabetic group):n=18 It was subdivided into
2 subgroups:_Control (group 3) :n=8 and MD subgroup (group 4) : $n=10$

All patients were followed for about 6 months. Mediternean diet subgroups followed a specially designed dietary regimen with specific macronutrient distribution and its principal aspects as stated by Dworatzek et $\mathrm{al}^{[15]}$ and ADA ${ }^{[16]}$.

Serum: Vaspin ${ }^{[17]}$, vitamin $\mathrm{D}^{[18]}$, random blood sugar, glycoslated haemoglobin A1c, $\mathrm{TC}^{[19]}$, insulin ${ }^{[20]}$. $\mathrm{C}^{[21]}, \mathrm{LDL}^{[22]}, \mathrm{TG}^{[23]}, \mathrm{SOD}^{[24]}$ and $\mathrm{MDA}^{[25]}$ levels, creatinine clearance ${ }^{[26]}$, BMI, $\mathrm{WC}, \mathrm{HOMA}^{[27]}$ and $\mathrm{AI}^{[28]}$ were assessed at the beginning and after 6 months:

\section{RESULTS}

Comment : After 6 months of ordinary diet and sedantry life style, an insignificant change was found in circulating levels of: vaspin, Vit.D, HbA1c, insulin, glucose, TC, HDL, LDL, TG, MDA and SOD and BMI, WC, HOMA, creatinine clearance in both group 1 and 3. While a significant increase in AI was found in group 1 and an insignificant change in group 3. Whileafter 6 months of mediterrnean diet, a significant decrease in BMI, W.C, AI and HOMA and circulating levels of vaspin, HbA1c, insulin, glucose, TC, LDL, TG, and MDA levels in both group 2 and 4. However, a significant increase in HDL, SOD and Vit.D levels in both group 2 and 4. In addition, there was a non significant change in creatinine clearance level group 2 with a significant increase in group 4. 


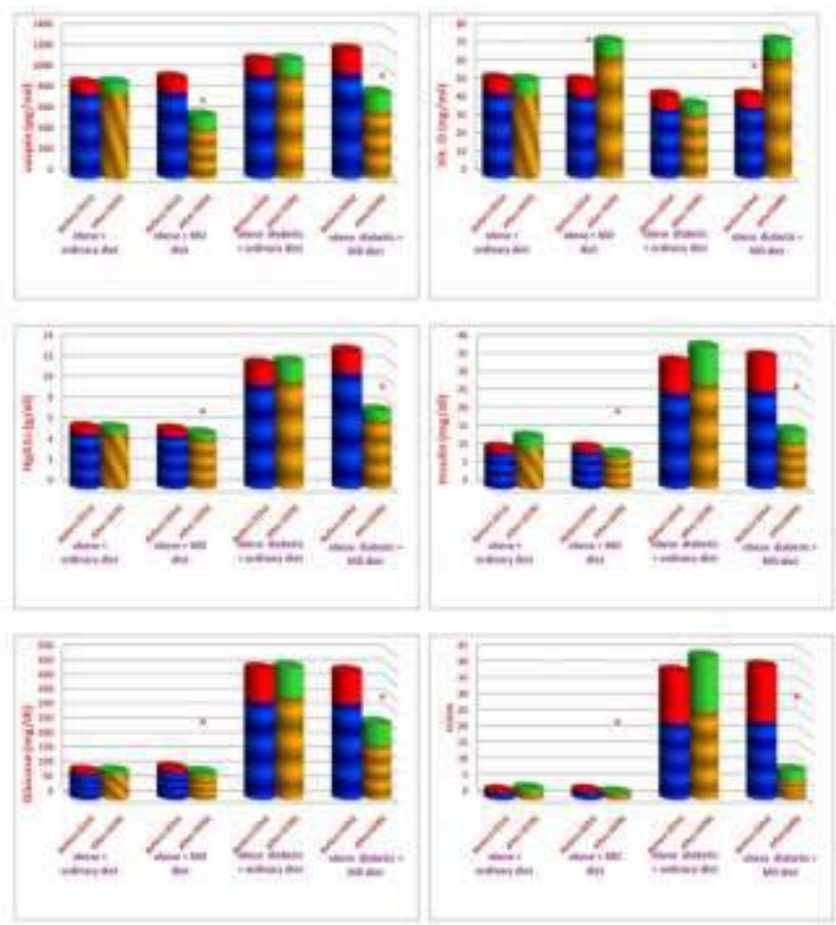

Fig. (1) Histograms illustrating the mean values of $\operatorname{Vaspin}(\mathrm{pg} / \mathrm{ml}), \mathrm{VitD}(\mathrm{ng} / \mathrm{ml}), \mathrm{HbA1c}(\mathrm{g} / \mathrm{dl})$, insulin(mg/dl), glucose(mg/dl) and HOMA levels in all studied groups.
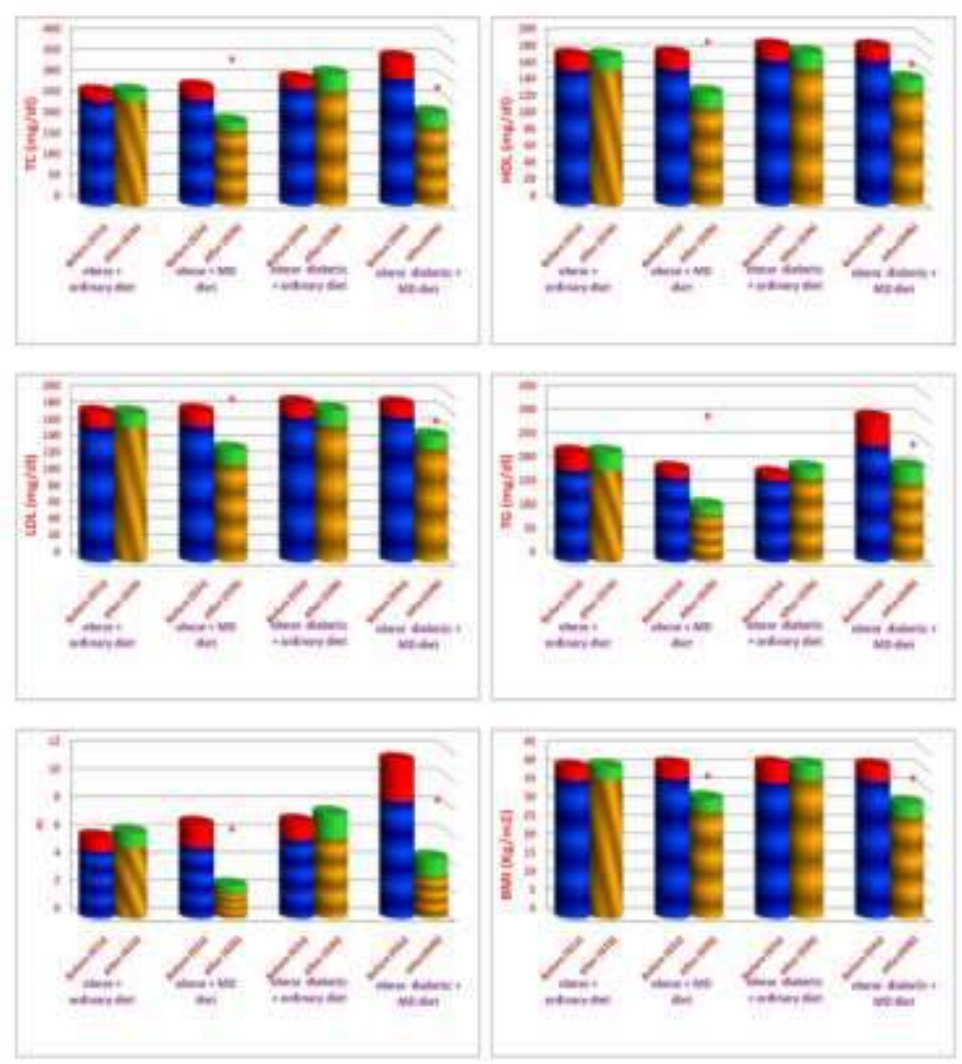

Fig. (2) Histograms illustrating the mean values of TC(mg/dl), HDL(mg/dl), LDL(mg/dl), TG(mg/dl), AI and BMI(kg/m2) levels in all studied groups. 

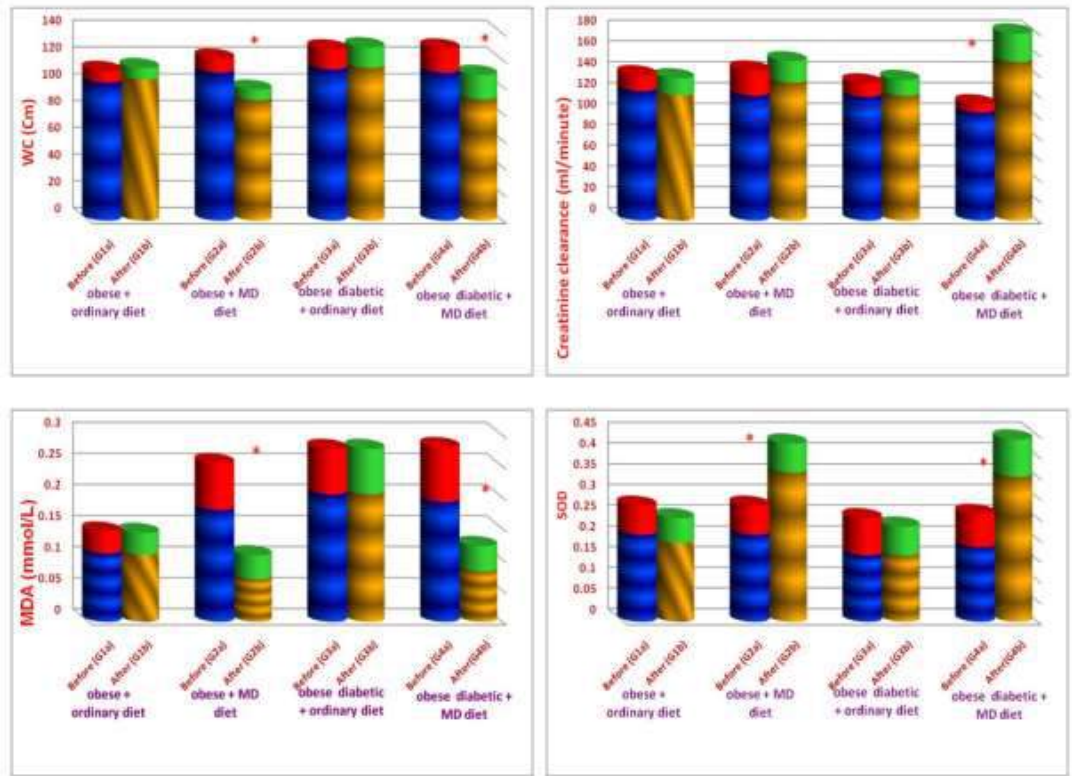

Fig. (3) Histograms illustrating the mean values of $\mathrm{WC}(\mathrm{cm})$, creatinine clearance $(\mathrm{ml} / \mathrm{minute})$, $\operatorname{MDA}(\mathrm{mmol} / \mathrm{l})$ and $\operatorname{SOD}(\mathrm{mmol} / \mathrm{l})$ levels in all studied groups.

Correlations between serum vaspin and vitD levels and all studied parameters in group 2B" obese non diabetic group after 6 months of following mediterrnean diet": Positive correlation was found between vaspin and $\mathrm{BMI}, \mathrm{WC}, \mathrm{HbA} 1 \mathrm{C}, \mathrm{HOMA}, \mathrm{TC}$, TG, LDL, AI and MDA "P<0.001, $\mathrm{P}<0.001$, $\mathrm{P}<0.001, \mathrm{P}<0.001, \mathrm{P}<0.05, \mathrm{P}<0.001, \mathrm{P}<0.01$, $\mathrm{P}<0.001$ and $\mathrm{P}<0.001 "$ and negative correlations with SOD, Creatinine clearance,
VitD and HDL "P<0.01, $\mathrm{P}<0.001, \mathrm{P}<0.001$ and $\mathrm{P}<0.01 "$. Moreover, Positive correlation was found between vitD and SOD, Creatinine clearance and $\mathrm{HDL} " \mathrm{P}<0.01, \mathrm{P}<0.001$ and $\mathrm{P}<0.01 "$. and negative correlations with BMI,WC, Vaspin, glucose, HbA1C, HOMA, TC, TG, LDL, AI and MDA "P<0.001, $\mathrm{P}<0.001, \quad \mathrm{P}<0.001, \quad \mathrm{P}<0.05, \quad \mathrm{P}<0.001$, $\mathrm{P}<0.001, \mathrm{P}, 0.01, \mathrm{P}<0.001, \mathrm{P}<0.01, \mathrm{P}<0.001$ and $\mathrm{p}<0.001 "$.
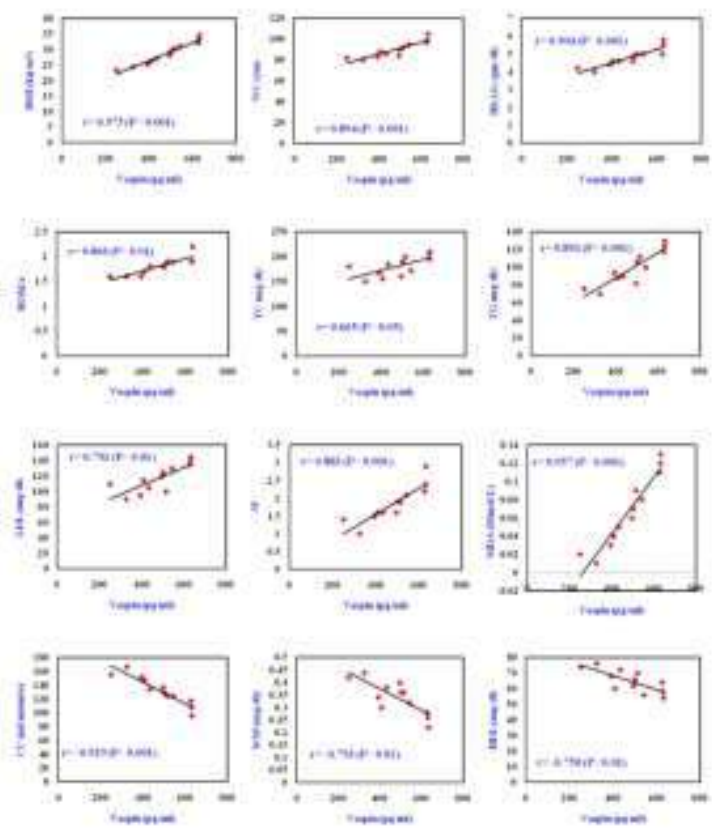

Fig. (4): Correlations between serum vaspin levels and all studied parameters in group 2B" obese non diabetic group after 6 months of following mediterrnean diet" 

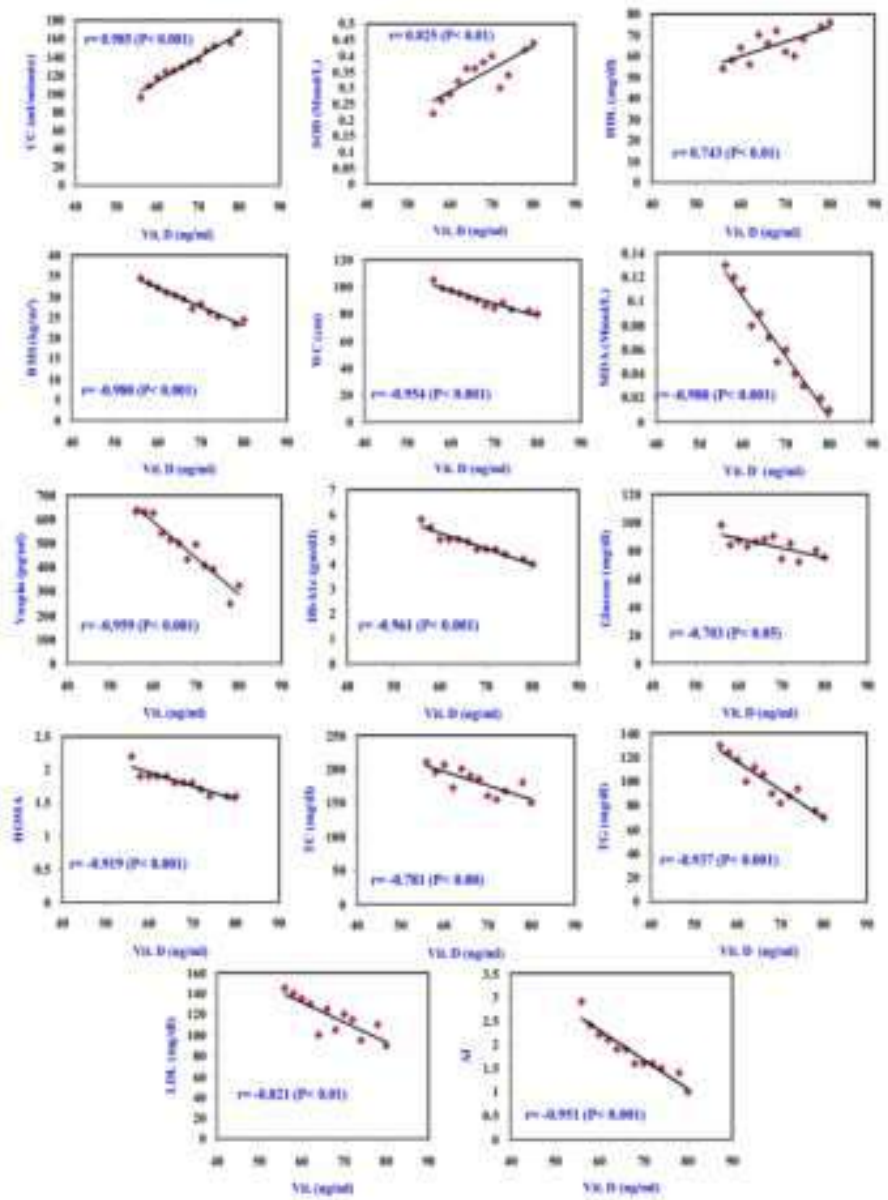

Fig. (5): Correlations between serum VitD levels and all studied parameters in group 2B" obese non diabetic group after 6 months of following mediterrnean diet"

Correlations between serum vaspin and vitD levels and all studied parameters in group 4B"obese diabetic group after 6 months of mediterrnean diet:Positive correlation was found between vaspin and BMI, WC, HbA1C, HOMA, glucose, TC, TG, LDL, AI and MDA "P<0.01, $\mathrm{P}<0.001$, $\mathrm{P}<0.01, \mathrm{P}<0.001, \mathrm{P}<0.01, \mathrm{P}<0.01, \mathrm{P}<0.01$, $\mathrm{P}<0.01, \mathrm{P}<0.001$ and $\mathrm{P}<0.001$ " and negative correlations with SOD, Creatinine clearance,
VitD and HDL "P<0.01, $\mathrm{P}<0.01, \mathrm{P}<0.01$ and $\mathrm{P}<0.01 "$. Moreover, Positive correlation was found between vitD and SOD, Creatinine clearance and HDL "P<0.01, $\mathrm{P}<0.001$ and $\mathrm{P}<0.01$ and negative correlations with "BMI, WC, Vaspin, HbA1C, HOMA, glucose, TC, TG, LDL, AI and MDA "P<0.001, $\mathrm{P}<0.001$, $\mathrm{P}<0.01, \mathrm{P}<0.001, \mathrm{P}<0.001, \mathrm{P}<0.05, \mathrm{P}<0.01$, $\mathrm{P}<0.001, \mathrm{P}<0.001, \mathrm{P}<0.001$ and $\mathrm{P}<0.001 "$. 

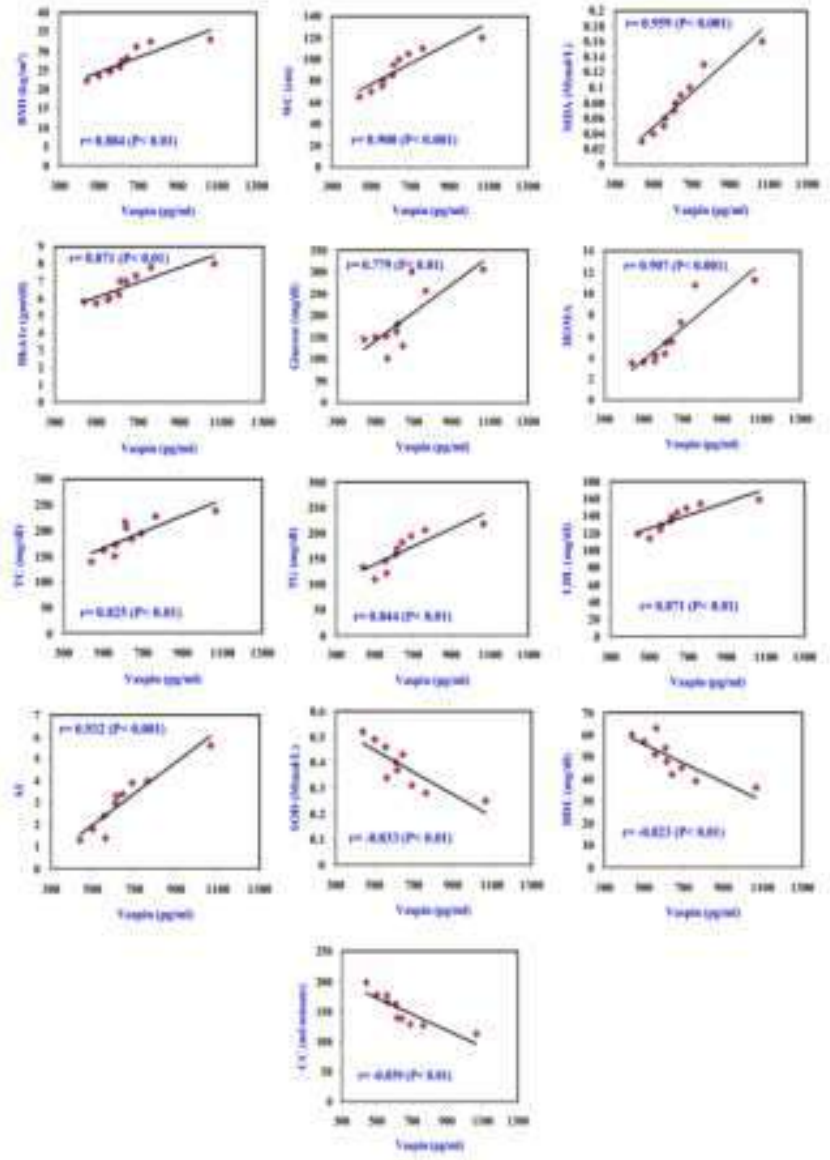

Fig. (6): Correlations between serum vaspin levels and all studied parameters in group 4B" obese diabetic group after 6 months of following mediterrnean diet"
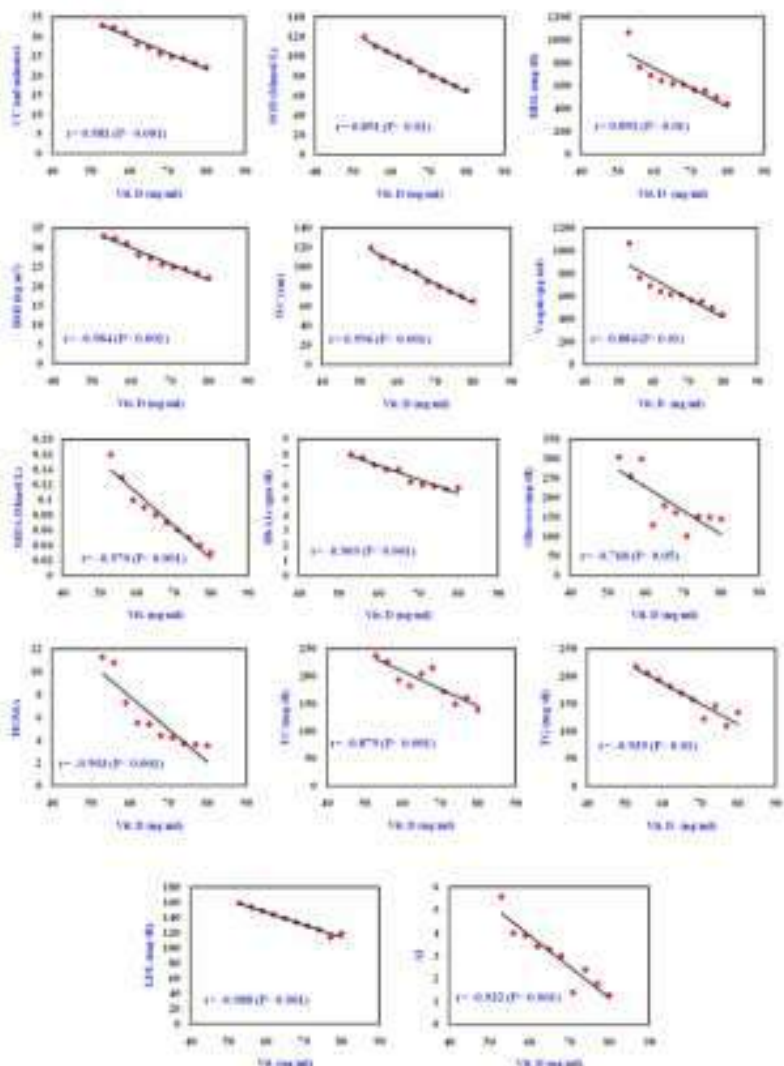

Fig. (7): Correlations between serum VitD levels and all studied parameters in group $4 B$ "obese diabetic group after 6 months of meditrenean diet 


\section{DISCUSSION}

Vaspin was firstly isolated from visceral white adipose tissues of abdominal obesity with type II diabetes mellitus Otsuka LongEvans Tokushima fatty rats ${ }^{[1]}$. The intimate relation between vaspin, obesity and diabetes is not understood, so our study was designed to explore the effect of dietary regimen on serum vaspin levels in obese diabetic and non diabetic female patients following mediaternean diet for 6 months.

Our results revealed an insignificant difference in serum vaspin levels in control groups after six months of ordinary diet besides a significant decrease in both obese and obese diabetic groups after 6 months of following mediternean diet. This came in accordance with li and youn et al. who found a decrease in serum vaspin level following long-term physical activity and in subjects with a BMI $<25 \mathrm{~kg} / \mathrm{m} 2$ [10,9]. Moreover, weight loss after following healthy life style resulted in diminished serum vaspin level ${ }^{\text {[29]. }}$

Similarly, a significant decrease in serum vaspin levels occurred in subjects who lost $\geq 2 \%$ of their base line weight ${ }^{[4]}$. Moreover, a reduction in serum vaspin level in acute weight loss after gastric bypass ${ }^{[30] .}$ However, an increase in serum vaspin level occurred in weight loss resulting from sharp increase in exercise in lean subjects [10]. Nevertheless, different weight loss intervenitions didn't affect serum vaspin level ${ }^{[12]}$. Also, No change in serum vaspin level occurred in prepubertal children following dietary intervention [13]. Moreover, no alteration in serum vaspin levels after life style modification for a 10 months in MetS patients ${ }^{[14]}$.

We suggest that this decrease in serum vaspin level after following mediterrnean diet for six months occurred due to chronic adaptation of its secretory level, fat mass reduction and healthy life style and that it increase in obesity as an adipokine hormone that increases when fat mass becomes greater as supported by Youn, Chang, Abd El Dayem and Ghahramani et al. who stated that fat mass expansion was associated with high circulating vaspin levels or as a compensatory mechanism against obesity- and insulin resistance-stimulated expression of certain proteases synthesized in abdominal fat $[\mathbf{9 , 4 , 3 1}$ and 32].

It can be postulated that vaspin, inhibits a protease which plays a role in the degradation of a hormone or molecule with direct or indirect glucose and lipid lowering effects ${ }^{\text {[33- }}$ 34]. These proteases blunt insulin action. Dimova and Tankova supposed that human kallikrein 7 (hK7) was a vaspin target ${ }^{[8]}$.

Our results also revealed a significant increase in vitamin D after 6 months of MD.In addition to a significant positive correlation between VitD and SOD, HDL and $\mathrm{CC}$ with a significant negative correlation between VitD and MDA, LDL, TG, TC, AI, BMI, WC, glucose, insulin and HOMA.

There are mainly four mechanisms which are used to explain the low level of vitamin D in the case of obesity: First; diminished sun exposure among obese people. Second, the reduction of $25(\mathrm{OH}) \mathrm{D}$ by negative feedback stemming from increased 1,25(OH)D2. Third, increased the uptake of vitamin $\mathrm{D}$ in adipose tissues. Fourth, the volumetric dilution of low 25(OH)D concentration ${ }^{[35]}$.

Another mechanism is the decrease in bioavailability in obese subjects. This means increase in body fat and decrease in serum $25(\mathrm{OH}) \mathrm{D}$ level. Decrease in body weight may cause increase of $25(\mathrm{OH}) \mathrm{D}$ concentration in peripheral tissues ${ }^{[36]}$.

There is also some evidence that vitamin $\mathrm{D}$ inhibits the development of adipocytes ${ }^{[37]}$. In vitro and in vivo studies suggest that PTH may promote fat accumulation and obesity through increases of calcium concentration within adipocytes; this increased intracellular concentration of calcium is also known to inhibit lipolysis ${ }^{[38]}$.

Regarding the significant negative correlation between VitD and vaspin which consized with Zorlu et al. ${ }^{[39]}$, this can be explained by the suggestion that preadipocytes possess vitamin D receptors ${ }^{[40]}$ Active form of vitamin $\mathrm{D}$ exerts different effects via different mechanisms by acting through these receptors, and by affecting adipokines.

Emerging evidence suggests that adipose tissue could be a target for vitamin D actions, as the 25-hydroxyvitamin D $1 \alpha$-hydroxylase 
and vitamin $\mathrm{D}$ receptor genes are expressed by adipocytes in both rodents and humans ${ }^{[41]}$ And in this way VitD could possibly affect the release of adipokines as vaspin from the adipose tissue ${ }^{[39]}$.Further studies are needed for a better understanding of the molecular mechanisms regulating vaspin, providing new insights into the pathogenesis of diet induced metabolic derangement and also to determine whether Vit. D supplementation in obesity and DM could improve these conditions.

\section{Declaration of interest}

The authors report no conflicts of interest. The authors alone are responsible for the content and writing of the paper.

\section{Funding information}

None declared

\section{REFERENCES}

1. Hida K., Wada J., Eguchi J.et al. Visceral adipose tissue-derived serine protease inhibitor: a unique insulin-sensitizing adipocytokine in obesity. Proc. Natl. Acad. Sci. U. S. A., 102: 10610-10615, 2005.

2. Moradi S., Mirzaei1 K., Abdurahman A. A.et al. Mediatory effect of circulating vaspin on resting metabolic rate in obese individuals . Eur J Nutr, 55:1297-1305, 2016.

3. Fain J.N., Buehrer B., Bahouth S.W.et al. Comparison of messenger RNA distribution for 60 proteins in fat cells vs the nonfat cells of human omental adipose tissue. Metabolism, 57:1005-1015, 2008.

4. Chang H.M., Lee H.J., Park H.S.et al. Effects of weight reduction on serum vaspin concentrations in obese subjects: modification by insulin resistance.Obesity , $18: 2105-2110$, 2010.

5. Von Loeffelholz C., Mo“hlig M., Arafat A.M.et al. Circulating vaspin is unrelated to insulin sensitivity in a cohort of nondiabetic humans. Eur. J. Endocrinol , 162 : 507-513, 2010.

6. Auguet T., Quintero Y., Riesco D.et al. New adipokines vaspin and omentin. Circulating levels and gene expression in adipose tissue from morbidly obese women. BMC Med Genet, 12(1):60, 2011.

7. Bashiri J., Rahbaran A., Gholami F.et al. The effect of acute exercise on serum vaspin level and its relation to insulin sensitivity in overweight elderly men. Zahedan Journal of Research in Medical Sciences, 16( 8 ) : 10-13, 2013.

8. Dimova R. and Tankova T. The Role of Vaspin in the Development of Metabolic and
Glucose Tolerance Disorders and Atherosclerosis. BioMed Research International, 2015.

9. Youn BS., Kloting N., Kratzsch J.et al. Serum vaspin concentrations in human obesity and type 2 diabetes. Diabetes, 57(2): 372-377, 2008.

10.Li Q., Chen R., Moriya J.et al. A novel adipocytokine, visceral adipose tissue-derived serine protease inhibitor (vaspin), and obesity. J Int Med Res, 36(4):625-629, 2008.

11.Blüher $M$. Vaspin in obesity and diabetes: pathophysiological and clinical significance. Endocrine, 41(2) : 176-182, 2012a.

12.Koiou E., Tziomalos K., Dinas K.et al. The effect of weight loss and treatment with metformin on serum vaspin levels in women with polycystic ovary syndrome. Endocr. J, 58 : 237-246, 2011.

13.Martos-Moreno G.A., Kratzsch J., Ko rner A.et al. Serum visfatin and vaspin levels in prepubertal children: effect of obesity and weight loss after behavior modifications on their secretion and relationship with glucose metabolism. Int. J. Obes. (Lond.), 35: 1355$1362,2011$.

14.Kim S.M., Cho G.J., Yannakoulia M.et al. Lifestyle modification increases circulating adiponectin concentrations but does not change vaspin concentrations. Metabolism , 60 : 1294-1299, 2011.

15.Dworatzek P.D., Arcudi K., Gougeon R.et al. Nutrition Therapy. Can J Diabetes ,37 : 45$55,2013$.

16.ADA. Standards of medical care in diabetes. Diabetes Care., 39(1):1-106, 2016.

17. Seeger J., Ziegelmeier M., Bachmann A.et al. Serum levels of the adipokine vaspin in relation to metabolic and renal parameters.J. Clin. Endocrinol. Metab., 93: 247-251, 2008.

18.Hollis B., MacFarlane G. and Valcour A. Clinincal significance and assessment of 25 $\mathrm{OH}$ vitamin D .Advance/Laboratory, 72-78, 2005.

19.Tietz N.W., Cook T. and McNiven, M.A. Clinical Guide to Laboratory Tests, W.B. Saunders, Co., Philadelphia, 509-12, 1995.

20.Temple R.C., Clark P.M. and Hales C.N. Measurement of insulin secretion in type 2 diabetes: problems and pitfalls. Diabetic Medicine 9: 503-12, 1992.

21.Nauck M. Marz W. and Jarausch, J. Multicenter evaluation of a homogenous assay for HDL-Cholesterol without sample pretreatment Clin Chem., 43:1622-29, 1997. 
22.Friedewald W.T., Levy R.I. and Fredrickson D.S. Estimation of the concentration of low-density lipoprotein cholesterol in plasma, without use of the preparative ultracentrifuge. Clin Chem., 18: 499-502, 1972.

23.Fossati P. Principle Lab. Clin Chem., 28:207779, 1982.

24.Kakkar P., Das B. and Viswanathan P.N. A modified spectrophotometric assay of superoxide dismutase. Indian $\mathbf{J}$ Biochem Biophys; 21(2): 130-132, 1984.

25.Ohkawa H., Ohishi W. and Yagi K. Assay for lipid peroxides in animal tissues by thiobarbituric acid reaction. Anal Biochem.; 95 (2): 351-358, 1979.

26.Cockcroft W.D. and Gault H.M. Prediction of creatinine clearance from serum creatinine. Nephron, 16 (1) : 31-41, 1976.

27.Matthews D.R., Hosker J.P., Rudenski A.S.et al. Homeostasis model assessment :insulin resistance and beta-cell function from fasting plasma glucose and insulin concentrations in man. Diabetologia, 28:412-19, 1985.

28.Schulpis K. and Karikas G.A. Serum cholesterol and triglyceride distribution in 7737 school aged Greek children.Paediatrics, 101:861-864, 1998.

29.Blu“her M., Rudich A., Klo“ting N.et al. Two patterns of adipokine and other biomarker dynamics in a long term weight loss intervention.Diabetes Care, 2011.

30.Handisurya A., Riedl M., Vila G.,et al. Serum vaspin concentrations in relation to insulin sensitivity following RYGB-induced weight loss. Obes. Surg., 20 : 198-203, 2010.

31.Abd El Dayem M. S, Battah A. A., El Bohy A.et al. Relationship of plasma level of chemerin and vaspin to early atherosclerotic changes and cardiac autonomic neuropathy in adolescent type 1 diabetic patients. J Pediatr Endocr Met., 28(3-4): 265-273, 2015.

32.Ghahramani M., Rohani H. and Ghiasi A. Post-Resistance Exercise Response of Vaspin
Adipocytokin and its Relation to Insulin and Glucose Levels in Overweight Women. Middle-East Journal of Scientific Research, 11 (10): 1328-1334, 2012.

33.Kloting N., Kovacs P., Kern M. et al. Central vaspin administration acutely reduces food intake and has sustained blood glucose lowering effects. Diabetologia , 54: 18191823, 2011.

34.Shaker OG.and Sadik NA. Vaspin gene in rat adipose tissue: relation to obesity-induced insulin resistance. Mol Cell Biochem., 373: 229-239, 2013.

35.Pourshahidi, L.K. Vitamin D and obesity: current perspectives and future directions. Proceedings of the Nutrition Society ,. 74(2): 115-24, 2015.

36.Rock C.L., Emond J.A., Flatt S.W.et al. Weight loss is associated with increased serum 25-hydroxyvitamin D in overweight or obese women.. Obesity, 20(11) : 2296-2301, 2012.

37.Reid I.R., Mason B., Horne A.et al. Effects of calcium supplementation on serum lipid concentrations in normal older women: A randomized controlled trial. Am J Med., 112(5):343-347, 2002.

38.Xue B., Greenberg A.G., Kraemer F.B.etal. Mechanism of intracellular calcium ([Ca2_]i) inhibition of lipolysis in human adipocytes. FASEB J., 15:2527-2529, 2001.

39.Zorlu M., Kiskac M., Cakirca M.et al. Evaluation of the Relation between Vitamin D and Serum Omentin and Vaspin Levels in Women.Exp Clin Endocrinol Diabetes , 124(7):440-3, 2016.

40.Lee S., Lee D.K. and Choi E. Identification of a functional vitamin D response element in the murine Insig-2 promoter and its potential role in the differentiation of 3T3-L1 preadipocytes.Mol Endocrinol, 19:399408,2005.

41.Ding C., Gao D. and Wilding J. Vitamin D signalling in adipose tissue. British Journal of Nutrition,108:1915-1923,2012.

To Cite This Article: Mansour SW, Tawfiq MS, KhalefaAA. Hadhoud SE ,ShorbgyEA. Effect of Diet Regimen on Serum Vaspin Level in Obese Diabetic Female Patients . ZUMJ 2019, 25 (5): 699-707. DOi: 10.21608/zumj.2019.10713.11170. 